\title{
A Review on Maximum Productivity of Land Use in Urban Project Development
}

\author{
Herlambang Sucahyo $^{1^{*}}$, Yani Rahmawati ${ }^{2 *}$ Christiono Utomo $^{3}$ \\ ${ }^{1}$ Institut Teknologi Sepuluh Nopember \\ ${ }^{2}$ Institut Teknologi Sepuluh Nopember \\ ${ }^{3}$ Institut Teknologi Sepuluh Nopember \\ *Corresponding author: ayaherlambang@gmail.com, yanirahmawati@mb.its.ac.id
}

\begin{abstract}
The Regional Budget Fiscal Year of Surabaya in 2017 is IDR 8,561,848,147,400, where Regional Revenue (PAD) is projected as much as IDR 4,212,569,176,921 along with Regional Wealth Management IDR 166,311,576,799. That revenue is derived from the activity of managing land asset. The total assets of Surabaya is currently $60,115,651.23 \mathrm{~m} 2$, where $84 \%$ of the area already has its land use, and $937,911.35 \mathrm{~m} 2$ or $0,56 \%$ is used for commercial use. Some of the assets are not optimally used for PAD yet. The city loses its opportunity in gaining maximal revenue because the assets are not developed properly, where the assets are mostly located in the main corridor of the city or primary artery. Highest and Best Use (HBU) analysis is found to be one of important technique in finding best alternative to be used in developing vacant land and existed improved property. This study analyzes the HBU practices in developing the government assets of Surabaya, especially the area that is placed near the riverside. Literature review and in depth interview to stakeholders are used to obtain data. The data is then analyzed by using descriptive analysis. Based on analysis, it is found that mixed use commercial building come out as best alternative in developing the assets.
\end{abstract}

Keywords- highest and best use, land use, land productivity

\section{INTRODUCTION}

Surabaya as the capital of East Java Province has

a strategic role at national scale as a service center of East Indonesia, and as a trade and service city at regional scale on national and international transportation node (land, air and sea). Those are giving opportunity for Surabaya to improve its role as a National Activity Center. Surabaya strategic location is deemed strategic since it regionally connects other cities in East Java, and nationally it connects with other cities in eastern Indonesia.

The population of Surabaya in 2015 reaches $2,848,583$ people, with population growth rate of $0.55 \%$ 2010-2015 and $0.52 \%$ in $2014-2015$. Over the last 5 years, Surabaya's economy has been able to grow steadily in the range of $6-7 \%$ [2]. The economic growth rate is higher compared to the average number of East Java and national economic growth. The economic growth of Surabaya has been slowing down since 2014 and 2015 in the range of $6 \%$, this growth slowdown is caused by global economic instability factor. This deceleration trend also occurs both at East and National level [16].

Along with the rapid growth rate, the development of macro-scale land use in Surabaya is still uneven, especially for economic, trade and service purpose. Surabaya Spatial Plan 2014-2034 shows that the development program for private sector are multifunctional areas between offices, trade/services and public facilities in one location. A single building must also be equipped with public utilities and facilities. This has become a mandate in development in accordance with the criteria established by the Regional Government [15]. This makes the optimum use of land asset in Surabaya contributes to improve PAD.

The Local Budget of Surabaya in the Fiscal Year of 2017 (APBD Tahun Anggaran 2017) is IDR $8,561,848,147,400$ and the Local Revenue (PAD) projection is IDR 4,212,569,176,921. There are also another revenue are gained from Segregated Property Wealth Management Outcomes and Business Services Levies amounting to IDR 166,311,576,799 of which came from revenues from the utilization of City Government assets [16]. The total area that is owned by the Surabaya City Government is $60,115,651.23 \mathrm{~m} 2$ and $50,538,671.12 \mathrm{~m} 2$ or $84.07 \%$ of the total land owned by the city government has been used, only $937,911.35 \mathrm{~m} 2$ is used as a trade and services/ commercial area [17].

The land assets which spread all over the city have not been optimally utilized. Similarly, the lands which the rental period have been expired are often abandoned. The management optimization of it is done by accommodating the planning discourses evolving in the region, the land can provide more services. Thus it can improve of the function as well as the land value and supports developments in a controlled manner. Based on previous issues, that functional/service alternatives can be proposed and can assign the best and highest function/service proposals, either for a single function or mixed use while still considering the benefits to society and quality improvement of the environment. This study aims to give the City consideration of land utilization 
and development policy with collaborative and participatory top-down planning.

\section{METHOD}

\section{A. Concept}

This study is an explorative study that aims to identify the most profitable, competitive use to which the subject property can be put. The data is obtained from literature review of previous studies. The main purpose of this explorative study is to identify the research situation and the specific objectives or data required for further studies in land use decision making. Explorative study is used because it aims to develop new knowledge or conjecture and provide direction for further study [13].

Explorative study is done when a number of facts are known, but much information is needed to construct a strong theoretical framework. In other words, explorative studies are essential in gaining a good understanding of phenomena and further equip science with further theoretical development and hypothesis testing.

\section{B. Design of the Study} order:

The steps in this study are arranged in the following

1. Planning.

a. Determining research object

b. Selecting research approaches, methods, and procedures.

2. Secondary data collection from literature studies including journals, textbooks, previous researches, and related provisions of the object and scope of the study.

3. Formulating hypotheses as a result of the study.

4. Reporting the results of the study in the form of conclusion and follow up.

\section{c. Methods of Data Collection}

To support the research, it is necessary to collect the data derived from secondary data through literature studies including regulations, research journals, reports and studies owned by academics, other researchers, government agencies, private associations, and companies which are related to the topic of this study namely the analysis on land value enhancement through the determination of asset land use. Some of these secondary data can be obtained from regional regulations, books, reports, magazines, journals, and other data related to this study or previous studies.

\section{RESULT AND DISCUSSION}

\section{A. Definition}

The intended properties in this study are land and/or buildings. A building is defined as a technical construction planted or fixed permanently on land and/or water. Properties classifies in 4 groups, which are: Residential Property consisting of two groups, which are: single family homes (freestanding homes, town homes) and multifamily homes (apartments, condominiums, cooperatives, planned unit developments); Commercial
Property, which consists of 2 groups, which are: Office Property, where the user of the building provides trade and services, and Retail Property, where the user of the building provides traded goods; Industrial Property, that includes all land or facilities used for industrial activities including warehousing, consisting of industrial real estate, light manufacturing or assembly, storage or warehouse/ office/distribution; Special Purpose Property, that are: hotels, motels, club houses, resorts, cinemas, schools, campuses, government offices, places of worship [14].

Land and building is one of the most popular areas of investment due to its ability in inflation. The value generated is likely to increase over the years rather than decrease. In respect of asset value, land mastery is an essential part in the government's balance of capital. In this regard, determining land use is an important factor in good governance and it is important to determine the right added value from its planning in addition to the land's actual value. A land use is the arrangement on how a land is supposed or not supposed to be used, so it can be inferred that a used land means a land that has a specific purpose/designation and is owned by a particular individual or institutions. In land use arrangement, one must make the best choices and decisions to use the land for a particular purpose that can be achieved [9].

Land use is the use of space both above and below the ground. So the use of land can be a projection of the space function, including the distribution of space that indicates the function or activity of the city concerned. The use of a land can be done by means of printing for various purposes such as road network and other utility infrastructure including housing, various types of government facilities (district office, fire station, etc.), social (education, health, open space), and commercial (markets, shops, etc.). Land use is closely related to the system of inter-human activity up to the institutional level i.e. individuals, households, companies, and each has different interests [4].

In site selection, it is necessary to consider the physical characteristics of the land such as usable area, geology, hazardous material, cultural resources and supporting infrastructure [18].

\section{B. Previous Studies}

The asset utilization uses top-down decision. During the deliberation process of this utilization, it is necessary to consider the collaborative approach which rises to new functions and supports the independence of key functions. Zhong [27] found that the discontinuity between area expansion and the decrease of city density resulted in many changes of allotment on agricultural land; it also affects construction, which gives an effect in urban population density. It is possible that there will be different levels of expansion effect in areas that have not been optimally developed yet, hence the need for government intervention in infrastructure development to help increase the value. The more productive a land is, the more issues may seem to arise from it. It will cause more challenges in improving land revenue.

Grissom [6] states that: each individual seeks not only to reflect on his personal interests but also the interests and purposes of others; the individual also can 
be invited to jointly develop his environment with a diversity of interests respectively. The study shows that is an emphasis on the essence of opinions submitted by stakeholders who need to put forward to achieve better regional values and also good communication and participatory process.

Ghavami [5] suggests adaptations of tiered and distributed models, the determination of collaborative parameters is required for top-down planning schemes and planner(s) are the key element on decision making in top-down planning. This makes planners still require the authority to combine the designs in top-down frameworks, as they come from multiple idea fragments, as well as the authority to distribute the idea so that it is politically acceptable throughout the plan area. This study aims to solve of the design conflicts that may occur in collaborative top-down assembly design; and extension to supporting the whole product design process including conceptual design; more validation experiments needs to be conducted [5].

Ozkaya [19] examined the relationships among orientations, knowledge competencies, market-based innovation, and firm performance, begin by defining all constructs and then develop the hypotheses. And the results are customer knowledge competence was a mediator of the relationship between customer orientation and market-based innovation; and that competitor knowledge competence was a mediator of the relationship between competitor orientation and marketbased innovation. This study also purposes market knowledge competence as a mediator of the relationships between market orientation and market-based innovations, and mediates the positive relationship between customer knowledge competence and firm performance.

There is also a valuation method, which is a measurement of land value based on the economic ability of land in relation to its productivity and economic strategy. In this case, the direct value of the land is a measure of the ability of the land to directly provide the value of productivity from its economic ability. Based on the categorization made by The Urban Land Institution (ULI), the property can be divided into 5 (five) major groups such as retail, residential, office, industry, hotel and resort, and mixed use [18].

\section{The Land Utilization Process Development}

A city is a place with a dense population, the houses are in a compact group and the livelihoods of the inhabitants are not agricultural. Cities can serve as places of service, marketing, distribution, transportation, industrial activities, worship and education. In addition, the dynamic characteristic of the economy can also be characterized, among others, by market distribution, land values, land use shifts and the spread of urban economic sectors such as trade and services sectors. Trade and services is one type of activity and space allocation that cannot be separated from urban elements. The definition of service is any action that can be offered by one party to another party, which is basically intangible and does not result in ownership of something. Service products may be related to physical products or not [11].
Sustainable Cities Institute [24] stated that TransitOriented Development (TOD) is a regional development approach that focuses on land use around transportation networks as transit points or along transit lines/areas. This development has some characteristics: a mix of uses, moderate to high density, pedestrian orientation/connectivity oriented, transportation options, minimum parking area (reduced parking) and high quality design. TOD itself is developed in a radius area of 400 meters (1/4 mile) or duration of 5 to 10 minutes of walk. By developing more 'urban scale' areas with minimal parking models and with the availability of access to transit, TOD is believed to improve air quality and help reduce traffic density.

That Transit Oriented Design (TOD) is a functional integration of land use and transit activities through the establishment of dense and multipurpose pedestrian friendly public facilities that can be reached on foot from public transport corridors or interaction nodes (For example: traffic intersections, markets, airports, etc.). In the study with emphasis on provision of public transport and humane infrastructure, the Pedestrian Oriented Design (POD) concept is also provided, this concept encourages the provision of pedestrian facilities to reach other public facilities. TOD and POD bring together a range of people, professions, and services and were designed efficiently, securely, comfortably and attractively for people to travel with public transport on an ongoing basis [8].

\section{Highest and Best Use Practices}

One approach to determine the function of land/property is reviewed it from the Highest and Best Use, where this approach is more favorable to market preferences or stakeholder opinions. The Appraisal Institute of Canada \& the Appraisal Institute [25] defines Highest and Best Use as vacant land or property enhancements that may be physically; legally supportive and financially feasible those produce the highest value. The Highest and Best Use rests on marketability analysis to identify the most competitive, most profitable use of the property. This use is shaped by a competitive boost in the area where the property is located and provides the foundation for a thorough investigation of the property position in the minds of market participants. Understanding market behavior developed through market analysis is essential for the Highest and Best Use concept.

The modern concept based on The Appraisal of Real Estate definition, the Highest and Best Use is the rational and possible use, which supports the highest present value or the use of some rational and legal alternative uses, the consideration of physically possible, it is supported by the financial feasibility and yield the value of the land, the highest value of the land [24].

The Highest and Best Use is defined as the possible legal and logical use of an empty or upgraded property, which physically, reasonably, and financially allowing it to deliver the highest value [25]. Cited from The Society of Residential (SSA), the best and highest use is a concept of appraisal that can be applied to lands or buildings which is usually interpreted as land use which 
will maximize the wealth of the owner through the most profitable use of the land [7].

Soeparjanto [21] defines the best and highest use in "The Appraisal of Real Estate" ie as fair and proportionate use that supports the current appraisal. This definition includes three main components of the analysis process which are selected from alternative use, physically and lawfully possible; and not a value judgment in the future.

Krestian [13] used the Highest and Best Use approach to determine the best supporting functional composition to the main function of the Keputran Market as a trading area. Begin by digging functions based on the opinions of stakeholders, including investors, bureaucrats, spatial observers and academics, the result of the research shows that the functions can be composed by the main function and the high value potential, resulting in three land use alternatives: merging the market with the diversification of the market business, market with rental housing, and market with parking building. The conclusion is the alternative of market and the diversification of market business is the best land use alternative that has the highest and best use on Keputran Market land with the property value equal to IDR $20,943,863.88 / \mathrm{m}^{2}$.

Rasyid [20] used the Highest and Best Use analysis approach to determine the main function of land in former gas station on Jalan Biliton Surabaya into shops (sales) and offices (rent) with the value of land amounting to IDR $16,457,465 / \mathrm{m} 2$ with maximum productivity up to $65 \%$. The result of the analysis obtained is single utilization on the land (single use) and there is no main function since the beginning, so the alternative function that emerged is equivalent.

Basuki [1] discussed the development of Joyoboyo terminal as a mixed use property while maintaining the main function as a terminal through the analysis of the highest and best use as an effort to increase the value of land use. The results showed that alternative shopping and modern shops can be an alternative activity that has the highest and best land use with increased land use productivity by $18 \%$ with the value of land/m2 of IDR $9,725,129$.

The research of HBU, can be further develop-ed by integrating the related topic with other field of study. Utomo et al. [28] integrated HBU with decision support and the concept of collaborative design to select best option in developing the urban heritage area.

From land use studies mentioned above, it can be concluded that in determining the designation of land assets, HBU approach can be safely used. This also applies in Surabaya land assets; the use of HBU has the best potential in investment and finance during the using period.

\section{CONCLUSION}

The result of this study shows that land utilization is emphasized on increasing land productivity, where the land of data is vacant land or improved existing land. In addition to the top-down planning process as policy implementation, it is possible to implement collaborative/participatory patterns from various stakeholders, including land use alternatives to stakeholder proposals.

The development and the determination of land use which can be done rationally is geared towards lands that have become the activity center or are about to be to boost efficiency and synergy in development planning at city scale. Using the Highest and Best Use approach by conducting an analysis of alternative land use proposals obtained from stakeholders based on criteria: legally permitted, physically and financially feasible, and has maximum productivity. Some studies indicate that one of land use alternatives that shows the highest land revenue is the commercial use, both single use and mixed use.

The short on revenue or budget has become an issue in financing the development and construction process of land use allocation. In this regard, the government tends to gear its development toward the optimization of public services, so if we want to increase the revenue, strategic efforts are needed during its implementation. The involved parties and stakeholders in the process of determining the use of government land assets are not limited only to the government as landowner; but the investors and communities are also involved. Thus we need active participation and collaboration in order to achieve the goal of maximizing land productivity by considering the market and environmental potential.

This also applies in collaborative planning, in which the environment potential, investment potential, and market projection have to be taken into account. In using the asset land of Surabaya City Government, the other party shall have profound understanding and knowledge about the regulations and enough financial resources considering there is expiration to this arrangement, which is maximum 30 years of land use permission in BOT/BTO regulation or 50 years arrangement through infrastructure provision cooperation (Kerja Sama Penyediaan Infrastruktur/KSPI) [8].

\section{REFFERENCES}

[1] Basuki, B., dan Utomo, C. Peningkatan Nilai Fungsi Penggunaan Lahan Terminal Joyoboyo di Kota Surabaya, Prosiding Seminar Nasional Manajemen Teknologi XXI Program Studi MMT-ITS, Surabaya, 2014.

[2] Badan Pusat Statistik, Surabaya dalam Angka, Jakarta, 2015.

[3] Brett, D.L., Schmitz, A., Real Estate Market Analysis : Methods And Case Studies ( $2^{\text {nd }}$ ed), 2009.

[4] Chapin, F. S and Kaiser, E.J., Urban Land Use Planning, Third Edition, Illinois : University of Illinois Press, 1979.

[5] Gao, S., Zhang, S., Chen, X., Yang, Y., A Framework For Collaborative Top-Down Assembly Design, Journal of Computers in Industry 64, 967-983, Elsevier B.V, 2013.

[6] Ghavami, S.M., Taleai, M., Arentze, T., Socially rational agents in spatial land use planning: A heuristic proposal based negotiation mechanism, Journal in Computers, Environment and Urban System 60, 67-78, Elsevier B.V, 2016.

[7] Grissom, T.V., The Semantics Debate : Highest and Best Use vs Most Probable Use, The Appraisal Journal, Vol. 51, No. 1, 45 - 57, The Appraisal Institute, 1983.

[8] Hansen-City Form Lab, Program Pembangunan Koridor Kota Surabaya, Singapore : The World Bank - The Australian Government, 2014.

[9] Homeland Ministry Act Number 19/2016, Jakarta, 2016 
[10] Jayadinata, J.T., Tata Guna Tanah dalam Perencanaan Pedesaan, Perkotaan dan Wilayah, Bandung : Penerbit

[11] Kotler, P., Kettler, K.L. (2009), Marketing Management, 13th Ed., Designing and Managing Services, New Jersey : Prentice Hall, 2009

[12] Krestian, I. dan Utomo, C., Analisa Peningkatan Nilai Penggunaan Lahan Pasar Keputran di Kota Surabaya, Prosiding Seminar Nasionnal Manajemen Teknologi XX, Surabaya, 2012.

[13] Kuncoro, M., Metode Riset Untuk Bisnis dan Ekonomi Bagaimana Meneliti dan Menulis Tesis, Edisi 3, Jakarta : Erlangga, 2003.

[14] Kyle, R.C., Property Management, Chicago : Dearborn Financial Publishing. Inc, 2005

[15] Local Regulation Number 14/2014, Surabaya City Spatial Plan Year 2014-2034, Surabaya, 2014.

[16] Local Regulation Number 10/2016, Surabaya Mid-term Development Planning Year 2016-2021, Surabaya, 2016.

[17] Local Regulation Number 15/2016, Surabaya City Budget Fiscal Year 2017, Surabaya, 2017.

[18] Miles, Mike E., Netherton, Laurence M., Schmitz, Adrienne, Real Estate Development : Principles And Process, 5th Edition, Washington DC : Urban Land Institute, 2015.

[19] Ozkaya, H. Erkan, Droge, Cornelia, Hult, G. Tomas M., Calantone, Roger, Ozkaya, Elif, Market Orientation, Knowledge Competence, and Innovation, International Journal of Research in Marketing 32, 309-318, Elsevier, 2015.

$$
\text { ITB, ,1999. }
$$

[20] Pearson,and Fanning, A Practical Method for Complying With R41c's Ighest and Best Use Requirement, The Appraisal Journal, 180-190, 1987.

[21] Rasyid, A., Desy, T. dan Utomo, C., Analisa Highest And Best Use (HBU) pada Lahan Bekas SPBU Biliton Surabaya, Jurnal Teknik Pomits Vol. 2, No. 2, Surabaya, 2013.

[22] Soeparjanto, Konsep Penilaian Properti, Jakarta : Pusat Pendidikan Dan Pelatihan Keuangan Umum, 2008.

[23] Sugiyono, Metode Penelitian Kuantitatif, Kualitatif dan $R \& D$, Bandung : Penerbit Alfabeta, , 2009.

[24] Sustainable Cities Institute, Transit Oriented Development, www.sustainablecitiesinstitute.org, 2013.

[25] The Appraisal Institute, The Appraisal of Real Estate, Twelfth Edition, Chicago : 2001.

[26] The Appraisal Institue of Canada \& the Appraisal Institute, The Appraisal of Real Estate - 3rd Canadian Edition, Canada : 2010.

[27] Zhong, Chen, Huang, Impact Of Land Revenue On The Urban Land Growth Toward Decreasing Population Density In Jiangsu Province, Journal of Habitat International 58, 34-41, Elsevier, China, 2016.

[28] Utomo, C., Rahmawati, Y., Suhartono, and Negoro, N.P. "A Concept toward Decision Support for Collaborative Urban Heritage Selection", Journal of Sustainable Development, vol. 8, no. 8, Surabaya, 2015. 